\title{
GENETIC DIFFERENCES AMONG NOBLE CRAYFISH (ASTACUS ASTACUS) STOCKS IN FINLAND, SWEDEN AND ESTONIA BASED ON THE ITS1 REGION
}

\author{
A. ALARANTA (1), P. HENTTONEN (1), J. JUSSILA (1, 2), H. KOKKO (1), T. \\ PRESTEGAARD (3), L. EDSMAN (3) \& M. HALMEKYTÖ (1)
}

(1) Institute of Applied Biotechnology, University of Kuopio, P.O. Box 1627, FIN-70211, Kuopio, Finland.

(2) Crayfish Innovation Centre, Salpaus Further Education, Päijänne-Institute, Meijeritie 1, FIN-17200 Vääksy, Finland.

(3) Institute of Freshwater Research, National Board of Fisheries, SE-17893, Drottningholm, Sweden.

Reçu le 23 juin 2005

Accepté le 26 janvier 2006

Received June 232005

Accepted January 26, 2006

\begin{abstract}
Noble crayfish (Astacus astacus) is indigenous to Finland. The distribution of $A$. astacus has diminished dramatically during the past century, due to environmental changes, crayfish plague (Aphanomyces astaci) outbreaks and stocking of alien signal crayfish (Pacifastacus leniusculus). Due to an active reintroduction policy and partly due to illegal introductions, the origins of noble crayfish populations are somewhat unknown. For conservation purposes it is essential to know if the populations are autochthonous or if they are a mixture of several different populations. Genetic variation of seven Finnish noble crayfish populations was studied comparing the variation in a short tandem repeat in the rDNA internal transcribed spacer 1 region (ITS1 region). Five Swedish and five Estonian populations were used as reference populations. Based on the ITS1 fragment variation, some of the analysed Finnish noble crayfish populations were most likely original populations or originated from one source population. They differed from the other populations according to the Population Divergence Test. However, there were no differences between some of the Finnish populations and this may be a consequence of multiple stockings. Differences among noble crayfish populations from the three countries were also studied. Five of the Finnish populations differed from the Swedish and the Estonian populations. One population, Lake Saimaa, did not differ from one Estonian and two Swedish populations. Furthermore, a population from northern Finland was not different from a population in northern Sweden. The Estonian populations had a larger number of fragments present in their genotypes compared to the Finnish and the Swedish populations. Private fragments, which were typical to only one country, were found in two Finnish, in four Estonian and in three Swedish populations.
\end{abstract}

Key-words: Noble crayfish, Astacus astacus, populations, genetic diversity, ITS1, Population Divergence Test, short tandem repeat. 


\section{DIFFÉRENCES GÉNÉTIQUES ENTRE LE STOCK FINLANDAIS, SUÉDOIS ET ESTONIEN D'ÉCREVISSES À PATTES ROUGES (ASTACUS ASTACUS) BASÉES SUR' LA RÉGION ITS1}

\section{RÉSUMÉ}

L'écrevisse à pattes rouges (Astacus astacus) est une espèce indigène de Finlande. Sa répartition a diminué remarquablement, en raison de changements environnementaux, d'épizooties dues à la peste de l'écrevisse (Aphanomyces astaci) et à l'introduction de l'écrevisse de Californie (Pacifastacus leniusculus). Due à une active politique de réintroductions et partiellement, à des introductions illégales d'écrevisses à pattes rouges, l'origine de ces populations est habituellement non connue. La variation génétique de sept populations finlandaises d'écrevisse à pattes rouges a été étudiée en comparant les variations d'un motif répété dans la région ITS1 de ADN ribosomique nucléaire. Cinq populations suédoises et cinq populations estoniennes ont été utilisées comme référence. Basé sur les variations de la taille du fragment ITS1, nous avons trouvé que la plupart des populations finlandaises étaient génétiquement d'origine. Cependant, il n'y a pas de différence entre certain des populations finlandaises indiquant une similarité génétique entre celles-ci. Cela peut être la conséquence de différents épisodes de translocations entre ces populations. Cinq populations finlandaises sont clairement différentes des populations suédoises et estoniennes mais une, celle du lac Saimaa, est génétiquement proche d'une population estonienne et de trois populations suédoises. De plus, une population du Nord de la Finlande est reliée à une population du Nord de la Suède.

Mots-clés : écrevisse à pattes rouges, Astacus astacus, populations, diversité génétique, ITS1, Test de divergence de population, short tandem repeat.

\section{INTRODUCTION}

Crayfisheries have a long history in Finland. Earliest reported noble crayfish (Astacus astacus) catches have been documented 150 years ago (LEHTONEN, 1975). Annual catches have collapsed from 20 million individuals to between 2 and 5 millions individuals from the beginning of the $20^{\text {th }}$ century to date (JUSSILA and MANNONEN, 2004). This collapse has been caused by changes in the aquatic environment, crayfish plague (Aphanomyces astaci) outbreaks and introduction of non-indigenous signal crayfish (Pacifastacus leniusculus), which coexists with crayfish plague in North America (WESTMAN and NYLUND, 1984; ABRAHAMSSON, 1973; HOLDICH and LOWERY, 1988; KIRJAVAINEN and WESTMAN, 1999; SKURDAL et al., 1999; WESTMAN; 2000; KILPINEN, 2003). When the commercial value of crayfish was discovered more than 100 years ago stockings of noble crayfish started widely and an active reintroduction practice was initiated. For management purposes, noble crayfish has been introduced to several Finnish water bodies repeatedly to regenerate collapsed populations, since the beginning of the $19^{\text {th }}$ century. This has resulted in numerous productive noble crayfish stocks, but on the other hand, it might have led to a loss of diversified populations since genetically different stocks have been mixed over time. To assist the government's noble crayfish conservation program it is essential to be able to distinguish differences among wild populations (HYYTINEN et al., 2000).

In $A$. astacus the ribosomal ITS region has been reported to be approximately $2,000 \mathrm{bp}$ long. In some other crustaceans they are: Astacus leptodactylus 2,300 bp, Pacifastacus leniusculus 2,100 bp, Pandalus borealis 1,600 bp and Nephrops norvegicus 1,800 bp (EDSMAN et al., 2002). Ribosomal genes (rDNA) are organized in a tandemly repeated manner. Each repeat contains a transcribed region which itself consists of the subunits $18 \mathrm{~S}, 5.8 \mathrm{~S}$ and $28 \mathrm{~S}$. The repeats also contain the external transcribed spacer 
ETS, and the internal transcribed spacers, ITS1 and ITS2, which are located on either side of the 5.8S gene (SHARMA et al., 2002; HESLOP-HARRISON, 2000). In A. astacus the ITS1 regions contain a microsatellite like insertion (GA-repeat), which has an intragenomic variation among the repeats, as well as the whole ITS region varies (EDSMAN et al., 2002, HARRIS and CRANDALL, 2000). Due to the localization of the repeat in a gene that is subject to a homogenizing mechanism among the gene copies (POLANCO et al., 1998), referred to as concerted evolution, the GA-repeat in the ITS1 region should not be treated as a codominant Mendelian marker. Homogenization of repeats has been assumed to be caused by unequal crossing over and gene conversion. The rate at which variant repeats become homogenized depends, for example, on the genetic drift, the relative number and size of repeats and the number of loci (e.g. NAGYLAKI, 1990; INSUA et al., 2003).

The number of rDNA genes varies depending on the organism (JOBST et al., 1998). According to PROKOPOWICH et al. (2003) the copy number in animals varies from 39 to 19,300 and in plants from 150 to 26,048 copies. Sequences of rDNA have been widely used when investigating phylogeny for organisms, with the ITS1 also being used in population studies due to its high level of sequence variation.

Investigation of the $A$. astacus GA -repeat in the ITS1 region near the $5^{\prime}$ end has been made recently in a population genetic study (EDSMAN et al., 2002). Altogether, 17 different fragments were identified, ranging in sizes between 162-210 bp. ITS fragments, as shown in EDSMAN et al. (2002), have potential to be used as markers in population investigations of $A$. astacus. ITS sequences have been used to analyse population differences or identification of species among decapods in the families Grapsidae, Palinuridae, Penaeidae (CHU et al., 2001), Portunidae (WEINBERG et al., 2003; IMAl et al., 2004), Cambaridae (HARRIS and CRANDALL, 2000). However, HARRIS and CRANDALL (2000) claim that high intragenomic variation, due to multiple insertions, can reduce the value of the ITS region in phylogenetic studies, e.g. for some decapods.

The aim of this study was to assess the usability of the fragments analysis of the ITS1 region, using the method described by EDSMAN et al. (2002), for genetic studies of the Finnish noble crayfish populations and to investigate population diversity among selected noble crayfish populations in Finland, Sweden and Estonia.

\section{MATERIAL AND METHODS}

\section{Specimens}

Finnish A. astacus samples were collected during the years 2003-2005. The stocking histories of these populations were obtained from local fishermen and government fisheries authority (Services for Farming and Fisheries of the Employment and Economic Development Center). A total of 8-30 crayfish specimens were collected from seven different locations in Finland (Table I). In addition, five Swedish and five Estonian populations with 20-49 crayfish from each site were used as reference populations (Table I).

\section{DNA extraction}

DNA was extracted from walking leg muscle. A small part of the muscle was removed using a wooden toothpick and placed in $500 \mu \mathrm{l}$ of buffer containing $100 \mathrm{mM}$ of Tris- $\mathrm{HCl}$ at $\mathrm{pH} 8.5,50 \mathrm{mM}$ of EDTA, $2 \%$ SDS, $20 \mathrm{mM}$ of $\mathrm{NaCl}$ and $100 \mu \mathrm{g}$ proteinase $\mathrm{K}$. The samples were lysed at $+37^{\circ} \mathrm{C}$ overnight. Then, $500 \mu \mathrm{l}$ of isopropanol was added, gently mixed and the tubes were centrifuged for $5 \mathrm{~min}$ at $7,000 \mathrm{rpm}$. The pellet was washed twice with $1,000 \mu \mathrm{l}$ of $70 \%$ ethanol and dried. Depending on the size of the pellet it was dissolved in 20-100 $\mu \mathrm{l}$ of TE (1 mM Tris, $0.1 \mathrm{mM}$ EDTA). DNA concentration was measured using spectrophotometer and the samples were stored at $-70^{\circ} \mathrm{C}$. 


\section{Table I}

The origins of the analysed Astacus astacus populations, the number of samples and the stocking history.

Tableau I

Origine des populations analysées, nombre d'individus testés et informations sur les repeuplements.

\begin{tabular}{|c|c|c|c|}
\hline No. & Population & $\mathbf{N}$ & Stockings \\
\hline \multicolumn{4}{|c|}{ Finland } \\
\hline 1 & River Siilinjoki & 30 & Yes, probably several origins \\
\hline 2 & River Sirkkakoski & 30 & Yes, probably several origins \\
\hline 3 & Farm at Köyliö & 30 & Yes, from Lake Köyliö \\
\hline 4 & Pond Ahvenlampi & 30 & No \\
\hline 5 & Lake Linkullasjön & 27 & No \\
\hline 6 & Lake Saimaa & 8 & Yes, probably several origins \\
\hline 7 & Pond Valkeisenlampi & 30 & Yes, probably several origins \\
\hline \multicolumn{4}{|r|}{ 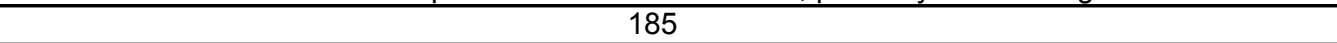 } \\
\hline \multicolumn{4}{|c|}{ Estonia } \\
\hline 8 & River Tirtsioja & 20 & Unknown \\
\hline 9 & River Karioja & 20 & Unknown \\
\hline 10 & Farm at Härjanurme & 20 & Unknown \\
\hline 11 & Farm at Angla & 30 & Unknown \\
\hline 12 & Lake Peipsi & 36 & Unknown \\
\hline \multicolumn{4}{|c|}{126} \\
\hline \multicolumn{4}{|c|}{ Sweden } \\
\hline 13 & Lake Aspen & 49 & No* \\
\hline 14 & Lake Bornsjön & 44 & No* \\
\hline 15 & River Råneälven & 45 & Yes, from South Sweden and North Finland* \\
\hline 16 & Lake Tjörnarpasjön & 43 & No* \\
\hline 17 & River Åsebyälven & 46 & No* \\
\hline \multicolumn{4}{|c|}{227} \\
\hline & Total & 538 & \\
\hline
\end{tabular}

\section{Polymerase chain reaction}

The PCR was performed using the specific ITS primers Asa1F (5'-tca ctc cgt cag cag tga gtc gct-3', Cy-5 labelled) and Asa 1R (5'-gag tca gct aga cgt gca gcc tag gcc c-3') (EDSMAN et al., 2002). The PCR reaction contained $100 \mathrm{ng}$ of DNA, $15 \mu \mathrm{l}$ of $\mathrm{H}_{2} \mathrm{O}, 2 \mu \mathrm{l}$ of $10 \times$ PCR buffer (Finnzymes), $20 \mu \mathrm{M}$ of dNTP, $20 \mu \mathrm{M}$ of each primer and $1 \mathrm{U}$ of DyNAzyme II DNA polymerase (Finnzymes). The PCR reaction consisted of one cycle for $5 \mathrm{~min}$ at $94^{\circ} \mathrm{C}$, followed by 30 cycles at $94^{\circ} \mathrm{C}$ for $30 \mathrm{~s}$, at $60^{\circ} \mathrm{C}$ for $30 \mathrm{~s}$, at $72^{\circ} \mathrm{C}$ for $60 \mathrm{~s}$ and finally one cycle at $72^{\circ} \mathrm{C}$ for $5 \mathrm{~min}$.

\section{Fragment analyses}

The fragment length analyses of the ITS1 repeats were made in the sequencing laboratory of A. I. Virtanen Institute (University of Kuopio, Finland). PCR products were loaded into the Hydrolink long read $6 \%$ gel and the fragments were separated using ALFexpress automated sequencer. In the electrophoresis, CY-5 labeled external size markers (50-250 bp in 50 bp intervals) and two internal size markers (50 bp and $250 \mathrm{bp}$ ) were used. Fragment sizes were determined using ALFwin Fragment Analyser (Pharmacia Biotech). 


\section{Population Divergence Test}

The Population Divergence Test (PDT) was performed in the Laboratory of Molecular Systematics (Swedish Museum of Natural History, Sweden). The Population Divergence Test measures the difference between population pairs in the fragment frequencies. The fragment lengths for each specimen are combined into a genotype (EDSMAN et al., 2002). The test produces probabilities ( $p$-values between 0 to 1) expressing the difference between two populations ( $p$-values $<0.05$ ), identical populations having value 1 .

\section{RESULTS}

The ITS1 fragment lengths varied from $162 \mathrm{bp}$ to $216 \mathrm{bp}$. A total of 22 different fragments were found: 15 fragments from Finnish, 17 fragments from Estonian and 13 fragments from Swedish samples (Figure 1, Table II). Fragments of $174 \mathrm{bp}, 182 \mathrm{bp}$ and $200 \mathrm{bp}$ were found only in the Estonian samples, referred to as private fragments (Table II). Furthermore, a fragment of $168 \mathrm{bp}$ was found in $80 \%$ and a fragment of $186 \mathrm{bp}$ was found in $82 \%$ of the Estonian samples. These fragments occur in the highest frequencies within the Estonian populations. The fragment of $172 \mathrm{bp}$ was frequently present in the Estonian and the Swedish samples, but absent in the Finnish samples. The frequency of fragments was more equally distributed in Finnish and Swedish samples. A total of $66 \%$ of the analysed Finnish samples had a fragment of $186 \mathrm{bp}$. Fragments of $204 \mathrm{bp}$ and $206 \mathrm{bp}$ were found only in the Finnish samples (private fragments). The fragment of $208 \mathrm{bp}$ was frequently present in the Finnish and the Estonian samples but absent in the Swedish samples. Fragments of $162 \mathrm{bp}, 178$ and $210 \mathrm{bp}$ were found only in the Swedish samples (private fragments) and the fragment of $198 \mathrm{bp}$ was found in $47 \%$ of the Swedish samples (Figure 1, Table II). At the population level, from 5 to 10 different fragments were observed in the Finnish, from 7 to 12 fragments in the Estonian and from 3 to 7 fragments in the Swedish populations. The number of different fragments in one individual varied from 1 to 5 and the average number of fragments was 2.6 in the Finnish, 3.1 in the Estonian and 1.8 in the Swedish samples. In the Finnish samples the average number of different genotypes was 11.6, in the Estonian samples 13.6 and in the Swedish samples 8.6 (Table II).

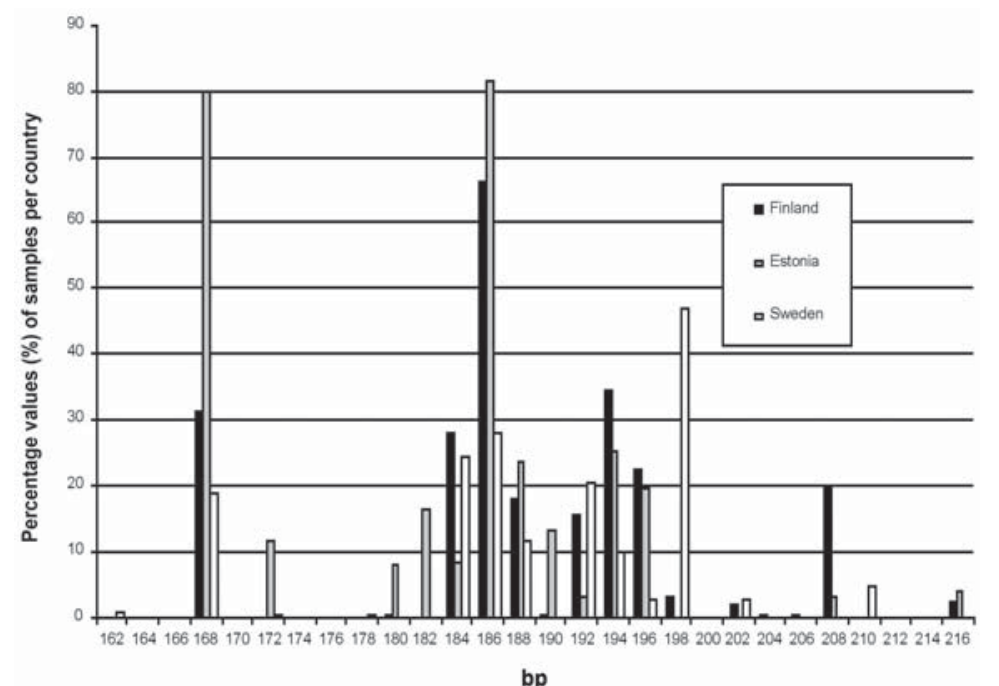

\section{Figure 1}

bp

The variation in the fragment pattern of the ITS1 region. Relative occurrence of different fragments in Finnish, Estonian and Swedish samples.

\section{Figure 1}

Variations de la taille du fragment ITS1. Pourcentage des différents tailles de fragments obtenus dans les populations finlandaises, estoniennes et suédoises. 


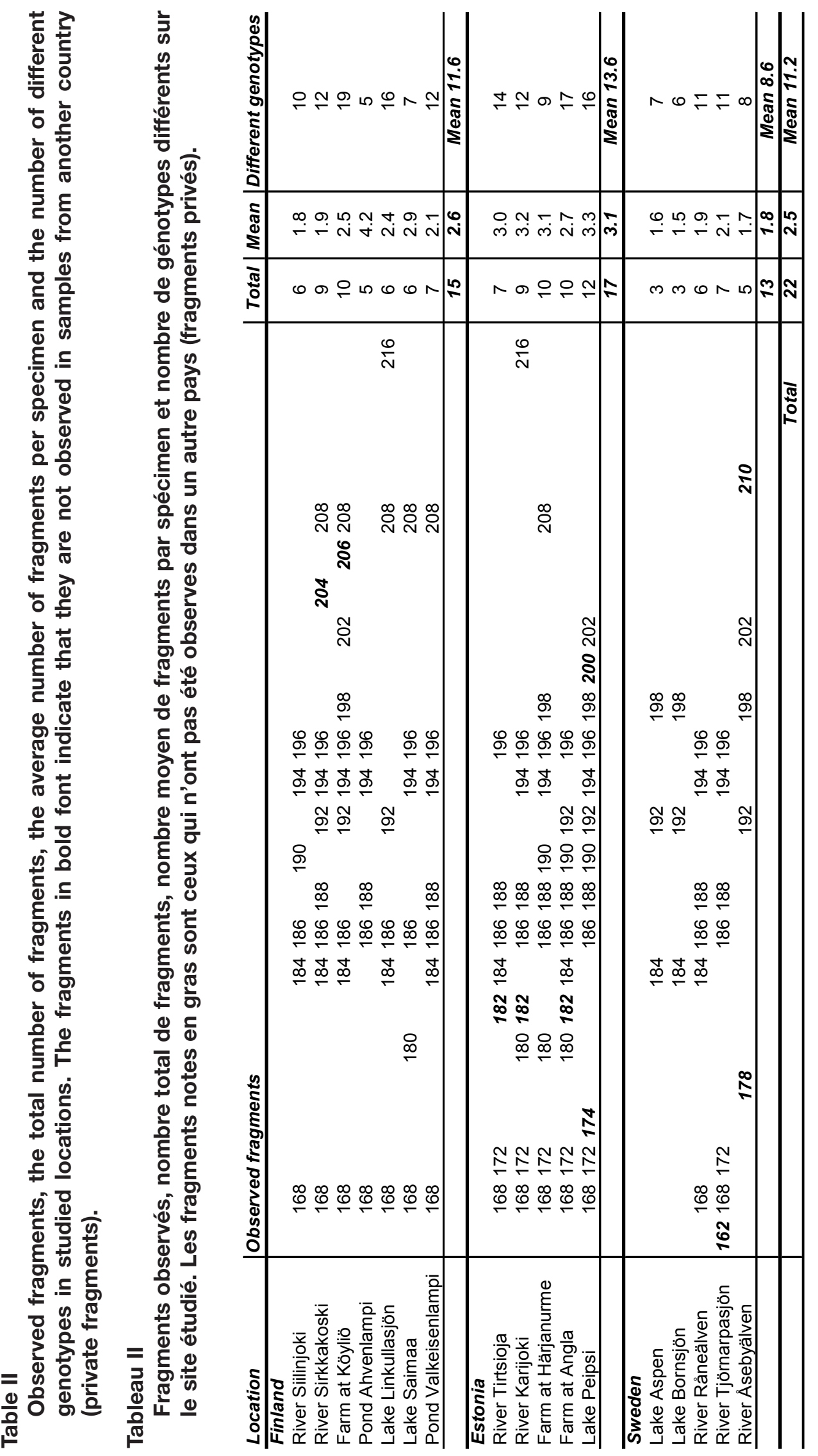


According to the PDT, the following populations were different ( $p$-values $<0.05)$ from all the other studied populations: Pond Ahvenlampi, Lake Linkullasjön and Köyliö crayfish farm (Finnish populations) and River Tirtsioja, River Karioja, Lake Peipsi and Angla farm (Estonian populations) and the Swedish population from River Åsebyälven. Differences were not statistically significant ( $p$-value $\geq 0.05$ ) in pair wise comparison between Lake Saimaa (Finland) and each of the following populations: River Siilinjoki (Finland), Pond Valkeisenlampi (Finland), River Råneälven (Sweden), River Tjörnarpasjön (Sweden) and a population from a crayfish farm in Estonia (Härjanurme farm). We did not observe any difference between River Råneälven (Sweden) and River Sirkkakoski (Finland) or between Lake Aspen (Sweden) and Lake Bornsjön (Sweden) (Table III, Figure 2).

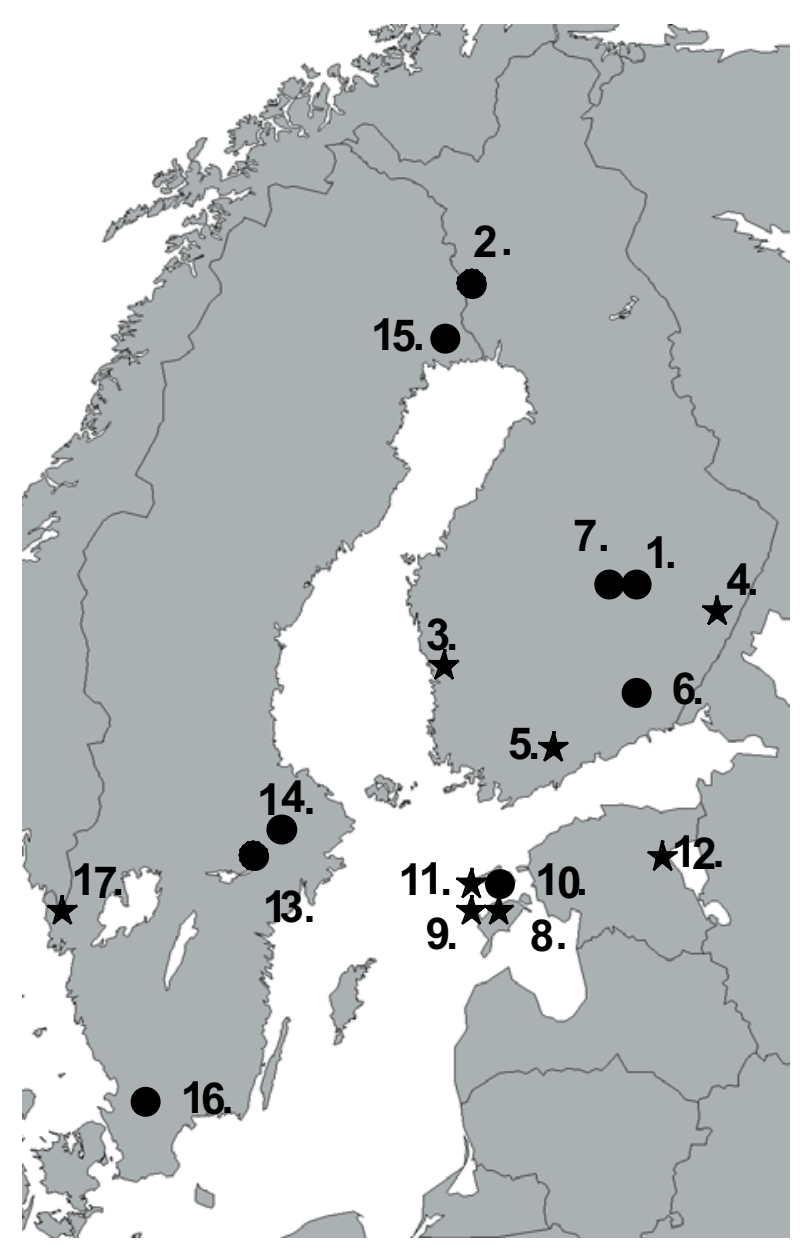

\section{Figure 2}

The geographical distribution of the analysed Astacus astacus populations. The populations which differ according to the PDT from all the other populations (p-values $<0.05)$ are marked with stars. Numbers of populations according to Table I.

\section{Figure 2}

Distribution géographique des populations d'Astacus astacus analysées. Les populations signalées par des étoiles ont une relation selon les test PDT avec un $p<0,05$. Les numéros des populations se réfèrent au tableau $I$. 


\section{Table III}

The results from the Population Divergence Test. Numbers present p-values for probability of difference between tested population pairs. Differences ( $p$ values $<0.05$ ) are highlighted in grey. Zeros indicate that $p$-values are lower than 0.00005 . Numbers of populations refer to Table $\mathrm{I}$.

\section{Tableau III}

Résultats des tests de divergence entre populations. Les nombres correspondent aux valeurs $p$ de probabilité de différence entre les populations. Les différences significatives $(p<0,05)$ sont colorées en gris. Les zéros indiquent des valeurs de $p<0,00005$. Les numéros des populations se réfèrent au Tableau $I$.

\begin{tabular}{|c|c|c|c|c|c|c|c|c|c|c|c|c|c|c|c|c|c|c|}
\hline Location & Population | & 1 & 2 & 3 & 4 & 5 & 6 & 7 & 8 & 9 & 10 & 11 & 12 & 13 & 14 & 15 & 16 & 17 \\
\hline \multirow[t]{7}{*}{ Finland } & 1 & 1 & & & & & & & & & & & & & & & & \\
\hline & 2 & 0.0192 & 1 & & & & & & & & & & & & & & & \\
\hline & 3 & 0 & 0 & 1 & & & & & & & & & & & & & & \\
\hline & 4 & 0 & 0 & 0 & 1 & & & & & & & & & & & & & \\
\hline & 5 & 0 & 0 & 0 & 0 & 1 & & & & & & & & & & & & \\
\hline & 6 & 0.0641 & 0.0373 & 0.0035 & 0 & 0 & 1 & & & & & & & & & & & \\
\hline & 7 & 0.0181 & 0.0089 & 0.0011 & 0 & 0 & 0.2994 & 1 & & & & & & & & & & \\
\hline \multirow[t]{5}{*}{ Estonia } & 8 & 0 & 0 & 0 & 0 & 0 & 0.0007 & 0 & 1 & & & & & & & & & \\
\hline & 9 & 0 & 0 & 0 & 0 & 0 & 0.0029 & 0 & 0.0001 & 1 & & & & & & & & \\
\hline & 10 & 0.0005 & 0.0001 & 0 & 0 & 0 & 0.1364 & 0 & 0.0006 & 0.0016 & 1 & & & & & & & \\
\hline & 11 & 0 & 0 & 0 & 0 & 0 & 0.0008 & 0 & 0.0014 & 0.0016 & 0.0235 & 1 & & & & & & \\
\hline & 12 & 0 & 0 & 0 & 0 & 0 & 0.0104 & 0 & 0 & 0 & 0.0012 & 0 & 1 & & & & & \\
\hline \multirow[t]{5}{*}{ Sweden } & 13 & 0 & 0 & 0 & 0 & 0 & 0 & 0 & 0 & 0 & 0 & 0 & 0 & 1 & & & & \\
\hline & 14 & 0 & 0 & 0 & 0 & 0 & 0 & 0 & 0 & 0 & 0 & 0 & 0 & 0.5742 & 1 & & & \\
\hline & 15 & 0.0008 & 0.0677 & 0 & 0 & 0 & 0.0725 & 0.0057 & 0.0001 & 0 & 0.0004 & 0 & 0 & 0 & 0 & 1 & & \\
\hline & 16 & 0 & 0 & 0 & 0 & 0 & 0.0628 & 0 & 0.0051 & 0.0042 & 0.0003 & 0 & 0 & 0 & 0 & 0 & 1 & \\
\hline & 17 & 0 & 0 & 0 & 0 & 0 & 0 & 0 & 0 & 0 & 0 & 0 & 0 & 0 & 0 & 0 & 0 & 1 \\
\hline
\end{tabular}

\section{DISCUSSION}

The ITS1 fragment analyse is a relatively simple instrument to investigate genetically distinct noble crayfish populations and in some cases to determine the origin of the population. Results based on the ITS1 fragment variation showed that some of the Finnish noble crayfish populations, namely Pond Ahvenlampi, Lake Linkullasjön and Köyliö crayfish farm, were different from all the other studied populations and they are most likely original populations or the stocking material originate from a single locality. This is in agreement with the known stocking history, obtained from fishermen and fisheries authorities in Finland. Populations that showed no difference could originate from multiple stockings or they could share same historical origin.

We also observed that the Estonian populations had higher number of fragments present in their genotypes compared to the Finnish and the Swedish populations. Fragments which are not present in other countries, private fragments, were only found in two Finnish populations, in four Estonian populations and in three Swedish populations. As a conclusion, using information of private alleles (presence or absence of them), it is possible to distinguish populations from different countries, but the occurrence of these private alleles needs to be studied in more detail by analysing more populations. 
River Råneälven (Sweden) and River Sirkkakoski (Finland) are both northern populations and no differences were found between them. This finding is in agreement with the known stocking history which confirms introductions of noble crayfish from north Finland to River Råneälven. These two populations shared same fragments even though River Råneälven (Sweden) has had introductions also from southern Sweden (EDSMAN et al., 2002).

Lake Aspen and Lake Bornsjön are both located in the county of Sörmland in central Sweden. There are no documented stockings into these waters (EDSMAN et al., 2002), and they were not different from each other. Short geographical distances or a common origin or both could explain this.

In regard to the Finnish crayfish stocks, populations from Pond Valkeisenlampi and River Siilinjoki did not differ from the Lake Saimaa population. Furthermore, the population in Lake Saimaa did not differ from one Estonian and two Swedish populations. Lake Saimaa is the largest lake in Finland and according to the known stocking history, there may have been several introductions to Lake Saimaa. Interestingly, almost all the samples of the Lake Saimaa population have a different genotype with a $180 \mathrm{bp}$ fragment and among the Finnish populations, they are the least different from Estonian and Swedish populations. Due to a small sample size and sampling from only one location in Lake Saimaa, further studies are needed and results so far should be treated with some caution.

High intragenomic variation (up to 5 fragments per crayfish and up to 12 fragments per population in our sampling) can be caused by reintroductions, or populations inhabiting large water systems with differentiated subpopulations. It can also be a result of multiple chromosome locations of the gene copies and, as a consequence, a less efficient homogenizing mechanism among the repeats (POLANCO et al., 1998). Populations without known stockings, such as the populations of Lake Linkullasjön and Pond Ahvenlampi, both from Finland, had less fragment variation in their genotypes. In Pond Ahvenlampi population we detected the lowest number of different genotypes. On the other hand, in the Köyliö crayfish farm population, ten different fragments and 19 different genotypes were present among 30 individuals. Despite this, these three populations were different from all the other populations. The management and stocking history in farms differs from the situation in wild. It could partly be the cause for the differences in the observed population diversity and genotype numbers.

The ITS1 region is a part of a multicopy gene and it is not assumed to have Mendelian inheritance (POLANCO et al., 1998; HARRIS and CRANDALL, 2000). Despite that, the ITS1 fragment variation can be used to analyse differences among populations, as demonstrated in this study. However, it would be important to know more about the copy number of the rDNA repeats and their location in the chromosomes as well as the inheritance mechanism. Microsatellites have been located for the related species Austropotamobius pallipes in a study on population characterization (GOUIN et al., 2000). It would also be interesting to compare results using different techniques, such as RAPDPCR (SCHULZ 2000), ISSR-PCR (SCHULZ et al., 2004) and microsatellites with several loci developed for $A$. astacus.

\section{ACKNOWLEDGEMENTS}

We would like to thank Arja Korhonen from A.I. Virtanen Institute (University of Kuopio, Finland) for the ALFexpress runs and Steve FARRIS from Laboratory of Molecular Systematics (Swedish Museum of Natural History, Sweden) for the Population Divergence Test runs. Also we would like to thank everybody who has helped us to get samples and information on the history of noble crayfish populations. This study was supported by the Ministry of Agriculture and Forestry and grants from Kuopio Naturalist's Society, NordForsk, The Finnish Cultural Foundation and Olvi Foundation. 


\section{REFERENCES}

ABRAHAMSSON S., 1973. The crayfish, Astacus astacus in Sweden and the introduction of the American crayfish Pacifastacus leniusculus. Freshwater Crayfish, 1, 28-40.

CHU K.H., LI C.P., HO H.Y., 2001. The first internal transcribed spacer (ITS-1) of ribosomal DNA as a molecular marker for phylogenetic and population analyses in Crustacea. Marine Biotechnology, 3, 355-361.

EDSMAN L., FARRIS J.S., KÄLLERSJÖ M., PRESTEGAARD T., 2002. Genetic differentiation between noble crayfish, Astacus astacus (L.), populations detected by microsatellite length variation in the rDNA ITS1 region. Bull. Fr. Pêche Piscic., 367, 691-706.

GOUIN N., GRANDJEAN F., SOUTY-GROSSET C., 2000. Characterization of microsatellite loci in the endangered freshwater crayfish Austropotamobius pallipes (Astacidae) and their potential use in other decapods. Molecular Ecology, 9, 629-644.

HARRIS D.J., CRANDALL K.A., 2000. Intragenomic variation within ITS1 and ITS2 of freshwater crayfish (Decapoda: Cambaridae): implications for phylogenetic and microsatellite studies. Molecular Biology and Evolution, 17, 284-291.

HESLOP-HARRISON J.S., 2000. Comparative Genome Organization in Plants: From Sequence and Markers to Chromatin and Chromosomes. Plant Cell, 12, 617-636.

HOLDICH D.M., LOWERY R.S., 1988. Crayfish - An introduction. In: HOLDICH D.M. and LOWERY R.S. (Eds.), 1988: Freshwater crayfish. Biology, management and exploitation. Croom Helm, London, 1-7.

HYYTINEN L., KIRJAVAINEN J., LAHTI E., MUHONEN J., MUNNE P., NIEMI A., SIPPONEN M. (HALONEN T. \& MANNONEN A.), 2000. Kalataloushallinnon rapustrategia. Kalaja riistahallinnon julkaisuja, 47, 44 p. Maa- ja metsätalousministeriö, Hämeenlinna. (In Finnish).

IMAI H., CHENG J.-H., HAMASAKI K., NUMACHI K-I., 2004. Identification of four mud crab species (genus Scylla) using ITS -1 and 16 S rDNA markers. Aquatic Living Resources, 17, 31-34. Abstract.

INSUA A., LÓPEZ-PIÑÓN M.J., FREIRE R., MÉNDEZ J., 2003. Sequence analysis of the ribosomal DNA internal transcribed spacer region in some scallop species (Mollusca: Bivalvia: Pectinidae). Genome, 46, 595-604.

JOBST J., KING K., HEMLEBEN V., 1998. Molecular evolution of the internal transcribed spacers (ITS1 and ITS2) and phylogenetic relationships among species of the family Cucurbitaceae. Molecular Phylogenetics and Evolution, 9, 204-219.

JUSSILA J., MANNONEN, A., 2004. Crayfisheries in Finland, a short overview. Bull. Fr. Pêche Piscic., 372-373, 263-273.

KILPINEN K., 2003. Suomen rapu. Ravun nousu, tuho ja tulevaisuus. Edita, Helsinki. 46 p. (In Finnish).

KIRJAVAINEN J., WESTMAN K., 1999. Natural history and development of the introduced signal crayfish, Pacifastacus leniusculus, in a small, isolated Finnish lake, from 1968 to 1993. Aquatic Living Resources, 6, 237-401.

LEHTONEN J.U.E., 1975. Kansanomainen ravustus ja rapujen hyväksikäyttö Suomessa. Kansantieteellinen arkisto, Suomen muinaismuistoyhdistys, Helsinki. 159 p. (In Finnish).

NAGYLAKI T., 1990. Gene conversion, linkage, and the evolution of repeated genes dispersed among multiple chromosomes. Genetics, 126, 261-276. 
POLANCO C., GONZÁLEZ A.I, DE LA FUENTE Á., DOVER G.A., 1998. Multigene family of ribosomal DNA in Drosophila melanogaster reveals contrasting patterns of homogenization for IGS and ITS spacer regions: a possible mechanism to resolve this paradox. Genetics, 149, 243-256.

PROKOPOWICH C.D., GREGORY t.r., CREASE T.J., 2003. The correlation between rDNA copy number and genome size in eukaryotes. Genome, 46, 48-50.

SCHULZ R., 2000. Status of the noble crayfish Astacus astacus (L.) in Germany: monitoring protocol and the use of RAPD markers to assess the genetic structure of populations. Bull. Fr. Pêche Piscic., 356, 123-138

SCHULZ H.K., ŚMIETANA P., SCHULZ R., 2004. Assessment of DNA variations of the noble crayfish (Astacus astacus L.) in Germany and Poland using inter-simple sequence repeats (ISSR). Bull. Fr. Pêche Piscic., 372-373, 387-399.

SHARMA S., RUSTGI S., BALYAN H.S., GUPTA P.K., 2002. Internal transcribed spacer (ITS) sequences of ribosomal DNA of wild barley and their comparison with ITS sequences in common wheat. Barley Genetics Newsletter, 32, 38-45.

SKURDAL J., TAUGBØL T., BURBA A., EDSMAN L., SÖDERBÄCK B., STYRRISHAVE B., TUUSTI J., WESTMAN K., 1999. Crayfish introductions in the Nordic and Baltic countries. In: GHERARDI F. and HOLDICH, D.M. (Eds.), 1999: Crayfish in Europe as alien species - how to make the best of a bad situation? Crustacean Issues, 11, A.A. Balkema, Rotterdam, 193-220.

WEINBERG J.R., DAHLGREN T.G., TROWBRIDGE N., HALANYCH K.M., 2003. Genetic differences within and between species of deep-sea crabs (Chaceon) from the North Atlantic Ocean. The Biological Bulletin, 204, 318-326.

WESTMAN K., NYLUND V., 1984. Rapu ja ravustus. Weilin+Göös, Espoo. 173 p. (In Finnish).

WESTMAN K., 2000. Comparison of the crayfish Pacifastacus leniusculus Dana, a species introduced into Finland, with the native species, Astacus astacus L., in allopatry and sympathy. Doctoral dissertation. 49 p. Department of Limnology and Environmental Protection, University of Helsinki, Helsinki. 
